\title{
Classification, diagnosis, and management of conjunctival lymphoma
}

\author{
Rebecca E. Tanenbaum, Anat Galor, Sander R. Dubovy and Carol L. Karp*
}

\begin{abstract}
Lymphoma is a malignant lymphoproliferative tumor that can involve the conjunctiva. Approximately 5-15\% of all extranodal lymphomas are found in the ocular adnexal region, with approximately $25 \%$ of those involving the conjunctiva. Ninety-eight percent of conjunctival lymphomas arise from B-lymphocytes. The most common subtype of conjunctival lymphoma is extranodal marginal zone lymphoma (80\%), followed by follicular lymphoma (8\%), diffuse large B-cell lymphoma (3\%) and mantle cell lymphoma (3\%). Natural killer and T cells (NK/T) are rare causes of lymphoma. While most conjunctival lymphomas are localized to the ocular adnexa at the time of presentation, systemic examination and management are of key importance in the long-term care of the patient.

This review outlines the classification, etiology, presentation, diagnosis, and management of conjunctival lymphoma. The novel use of high resolution optical coherence tomography, both as a diagnostic tool and as a means for ongoing evaluation during treatment, is illustrated. Treatment options discussed include external beam radiation, chemotherapy, immunotherapy, antibiotic therapy, and combination regimens. Future investigation of the etiology and pathogenesis of conjunctival lymphoma is expected to reveal opportunities for innovative and individualized therapeutic agents. Collaboration between multiple disciplines is key in the advancement of the field.
\end{abstract}

Keywords: Conjunctiva, Conjunctival tumor, Extranodal marginal zone lymphoma, Lymphoma, Optical coherence tomography, Salmon patch

\section{Background}

The conjunctiva is an important site of extranodal lymphoma development, which comprises $25-30 \%$ of all lymphomatous disease [1, 2]. While less common than conjunctival squamous neoplasia or melanoma, conjunctival lymphoma accounts for a significant portion of ocular adnexal lymphomas (OALs) (25\%) [3, 4]. If not detected or followed properly, the disease may progress systemically. Histologic subtype, as well as other characteristics such as laterality, is a critical predictor of prognosis and management. Many clinicians may not regularly encounter these tumors in practice, and thus feel uncomfortable managing the disease. This paper provides a comprehensive review of conjunctival lymphoma including classification, histology, staging, etiology, diagnostic methodology, recommendations for systemic evaluation, treatment, and prognosis. The purpose is to provide a comprehensive manual with an updated literature review of this entity for general and subspecialty ophthalmologists. In addition to this in-depth review, we report on the novel use of optical coherence tomography (OCT) technology in the diagnosis and monitoring of this disease.

\section{Review}

A thorough PubMed search of articles published between January 1990 and July 2018 on the diagnosis and management of conjunctival lymphoma was performed. Searches included a combination of the following terms: "bendamustine," "conjunctival lymphoma," "ocular adnexal lymphoma," "extranodal marginal zone lymphoma," "optical coherence tomography," "radiation therapy," "chemotherapy," "Chlamydia psittaci," "doxycycline," "interferon-alpha," and "rituximab." Pertinent articles were carefully reviewed and referenced in this paper.

\section{Classification}

The histology and clinical stage of conjunctival lymphomas are the most important predictors of disease outcome. 


\section{Histopathology}

The histological subtypes of lymphoma are divided into low- and high-grade categories (Table 1). Conjunctival lymphomas are most commonly extranodal marginal zone lymphoma (EMZL) and follicular lymphoma (FL), both of which are generally low-grade. EMZL, previously known as mucosa-associated lymphoid tissue (MALT) lymphoma, constitutes approximately $80 \%$ of conjunctival B-cell non-Hodgkin lymphomas (NHL). EMZL is slightly more common in female patients and typically presents in the patient's sixties $[3,5]$. FL is the second most common conjunctival lymphoma subtype, comprising approximately $8 \%$ of tumors. It also commonly presents in the seventh decade of life $[3,6]$.

Diffuse large B-cell lymphoma (DLBCL) and mantle cell lymphoma (MCL) are high-grade subtypes that each comprise approximately $3 \%$ of conjunctival lymphomas. These less common and faster-growing lymphomas most often occur in male patients in their seventies. Non-B-cell conjunctival lymphomas, derived from $\mathrm{T}$ lymphocyte or natural killer cells, are uncommon and carry a particularly poor prognosis, with a high predilection for systemic dissemination. Data on these lymphomas is scarce [3, 7-12].

\section{Staging}

Extent of regional nodal and distant systemic involvement at the time of diagnosis is part of the classification and staging of extranodal lymphoma. Most conjunctival lymphomas present as isolated disease without evidence of prior or concurrent systemic dissemination (67-90\%) [3, 13-19]. The incidence of systemic disease is less frequent with low-grade subtypes than with high-grade subtypes [19-23]. Of the high-grade conjunctival lymphomas, approximately $25 \%$ of patients with DLBCL and 50\% of patients with MCL have evidence of systemic lymphoma at the time of diagnosis. Up to $80 \%$ of T-cell NHL in the conjunctiva arise as secondary lymphomas from a distant source [3]. With any subtype of conjunctival lymphoma, long-term follow-up is key as systemic disease may develop months or years after the initial diagnosis [7, 15, 24].

\section{Etiology}

The etiology of conjunctival lymphoma remains elusive. Predisposing factors that have been linked to the development of OAL include: immune deficiency or dysfunction, autoimmune conditions (e.g. Sjögrens, autoimmune thyroid disease, systemic lupus erythematosus, rheumatoid arthritis) [3, 5, 25-30], infectious etiologies, genetic mutations, and prior radiation exposure. Conjunctival lymphoma appears to develop as a result of chronic inflammation triggered by endogenous or exogenous antigens, leading to sustained proliferation that permits the potential for genetic mutations leading to eventual monoclonal $\mathrm{B}$ or $\mathrm{T}$ lymphocyte populations [3, 5, 25-27]. Chronic benign reactive lymphoid hyperplasia of the ocular adnexa may induce such a malignant transformation, but the incidence of lymphoma in these cases has been low $[19,25,28,29,31]$.

Chronic antigenic stimulation associated with the pathogenesis of conjunctival lymphoma has also been associated with infectious agents including Chlamydia psittaci, Chlamydia pneumoniae, hepatitis C, and Helicobacter pylori $[3,26,27,30]$. Some studies have named $C$. psittaci as a principal causative agent in EMZL of the ocular adnexa, while other studies have failed to show any evidence of association [17, 32-34]. The prevalence of C. psittaci appears to vary geographically $[5,26,32,35$, 36]. Ferreri et al. reported hepatitis $C$ virus seropositivity in $13 \%$ of patients with OAL [37]. While H. pylori has been explicitly linked to the development of MALT lymphoma in the stomach, similar affiliations between this infectious agent and lymphoma of the conjunctiva are suspected but not yet confirmed.

Several genetic translocations, inactivating mutations, and trisomies (in particular trisomy of chromosomes 3 and 18) have been linked with various subtypes of conjunctival lymphoma $[3,5,18,26,30]$.

\section{Presentation}

Conjunctival lymphoma classically presents as a chronic, sessile, pink-colored sub-epithelial conjunctival mass described as a "salmon patch" (Fig. 1) [5, 27, 38]. Another presentation is that of a chronic follicular conjunctivitis (Fig. 2) [39]. Feeder vessels and rapid growth are not typically seen in lymphoma. Patients may be asymptomatic or note ocular irritation, redness, and, rarely, ptosis or exophthalmos (in cases with significant orbital involvement) $[3,16,27,40]$. The relatively asymptomatic initial

Table 1 Epidemiology of histologic subtypes of conjunctival lymphoma

\begin{tabular}{lllll}
\hline Histologic subtype & Histologic grade & Percentage of conjunctival lymphoma & Gender predilection & Median age \\
\hline EMZL & Low-grade & $80 \%$ & Female & $60 \mathrm{~s}$ \\
FL & Low-grade & $8 \%$ & Comparable & $60 \mathrm{~s}$ \\
DLBCL & High-grade & $3 \%$ & Male & $70 \mathrm{~s}$ \\
MCL & High-grade & $3 \%$ & Male & $70 \mathrm{~s}$ \\
T-cell NHL & High-grade & $2 \%$ & Comparable & Insufficient data
\end{tabular}

$E M Z L=$ extra-nodal marginal zone lymphoma; $F L=$ follicular lymphoma; $D L B C L=$ diffuse large B-cell lymphoma; $M C L=$ mantle cell lymphoma 


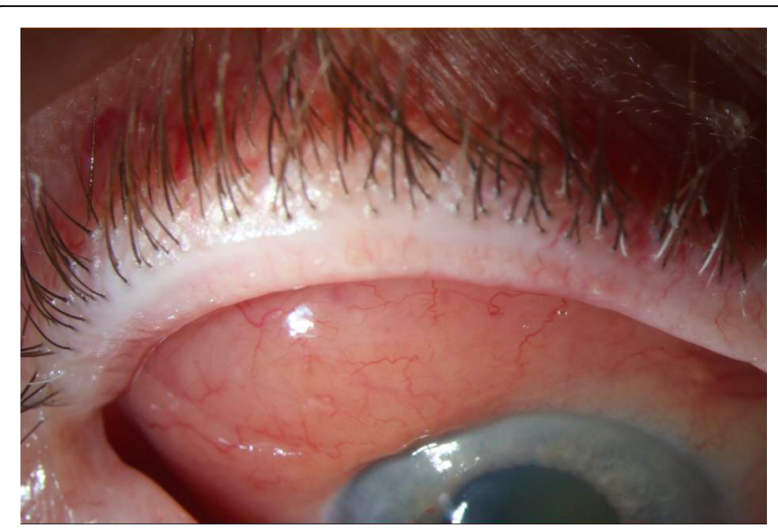

Fig. 1 Slit lamp image of right eye with "salmon patch" conjunctival lesion in the superior temporal conjunctiva. The biopsy confirmed lymphoma

presentation, especially with low-grade subtypes, often leads to a delay in diagnosis [26]. B-cell NHL lesions are typically found in the conjunctival fornix or bulbar region, and less commonly in the caruncle or limbus $[3,40,41]$. In contrast, $30 \%$ of T-cell lymphomas occur in the limbus [3]. Bilateral lesions account for $10-15 \%$ of cases of conjunctival lymphoma overall $[16,42]$. However, more than $50 \%$ of cases of the MCL subtype have bilateral involvement $[3,30]$.

\section{Diagnosis}

The differential diagnosis includes: benign lymphoid hyperplasia, episcleritis, conjunctival amyloidosis, atypical pterygium, amelanotic melanoma, pyogenic granuloma, chronic conjunctivitis, and, rarely, squamous cell carcinoma or papilloma.

\section{Optical coherence tomography}

Recently, a novel approach has been introduced in the diagnosis of ocular surface tumors with the help of high resolution anterior segment optical coherence tomography (HR-OCT) [38, 43-45]. The use of HR-OCT in the evaluation of patients with conjunctival lesions is rapid and

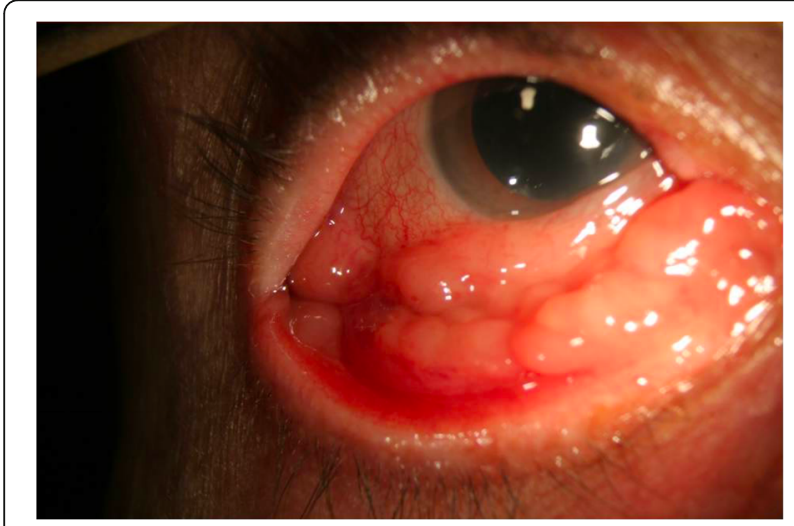

Fig. 2 Conjunctival lymphoma in the right eye of a patient presenting as a chronic follicular conjunctivitis non-invasive, and the results can easily be interpreted and utilized [46]. OCT generates a cross-sectional image of tissue layers by compiling multiple interference patterns from light reflected on the ocular surface [38]. Characteristic findings of conjunctival lymphoma on OCT have been determined by several studies in the past decade. Using HR-OCT imaging, the lesion is identified as a hyporeflective, homogenous subepithelial mass that appears to be composed of monomorphic, stippled, hypo-reflective dots (Fig. 3). Epithelial appearance and thickness is normal in lymphoma cases. The lesion may be surrounded by a hyper-reflective band of substantia propria, which likely represents conjunctival tissue displaced by the underlying mass. While HR-OCT cannot distinguish benign reactive lymphoid hyperplasia from lymphoma, there are visible differences between lymphoma and other subconjunctival infiltrates. For example, the distinctive dark, monotonous 'dots' of conjunctival lymphoma are differentiated from the hyper-reflective 'lines' within the subconjunctival mass that characterize amyloid infiltrate [38, 45].

Limitations of HR-OCT in the diagnosis of ocular adnexal lesions include difficulty scanning lesions of substantial thickness due to shadowing and poor detection of stromal invasion. However, HR-OCT has been recognized as an exceptional tool in the monitoring of disease resolution during treatment (Fig. 4). Case studies have shown that normalization of conjunctival architecture on OCT correlates well with completion of treatment and lesion resolution. In some cases, HR-OCT detected residual thickening or evidence of disease that was not visualized on clinical examination after initial treatment was concluded [38, 43, 45].

\section{Biopsy}

Surgical biopsy and histopathological examination are necessary to establish the diagnosis of conjunctival lymphoma. It is important to perform fresh tissue processing for both flow cytometry and gene rearrangement studies as clinical examination and radiographic studies alone are unable to distinguish malignant lymphoma from benign lymphoid hyperplasia [26, 30, 38, 47]. A portion of the biopsy should also be placed in formalin for histopathology (hematoxylin and eosin staining) and immunohistochemical staining.

\section{Systemic work-up}

Once conjunctival lymphoma is diagnosed, the extent of systemic disease should be established with a complete work-up by an oncologist. Work-up typically includes: complete blood count (CBC), serum chemistry studies (including lactate dehydrogenase (LDH)), computed tomography $(\mathrm{CT})$ or magnetic resonance imaging (MRI) of the orbit, CT scan of other commonly affected areas (neck, chest, abdomen, pelvis), full-body positron emission 


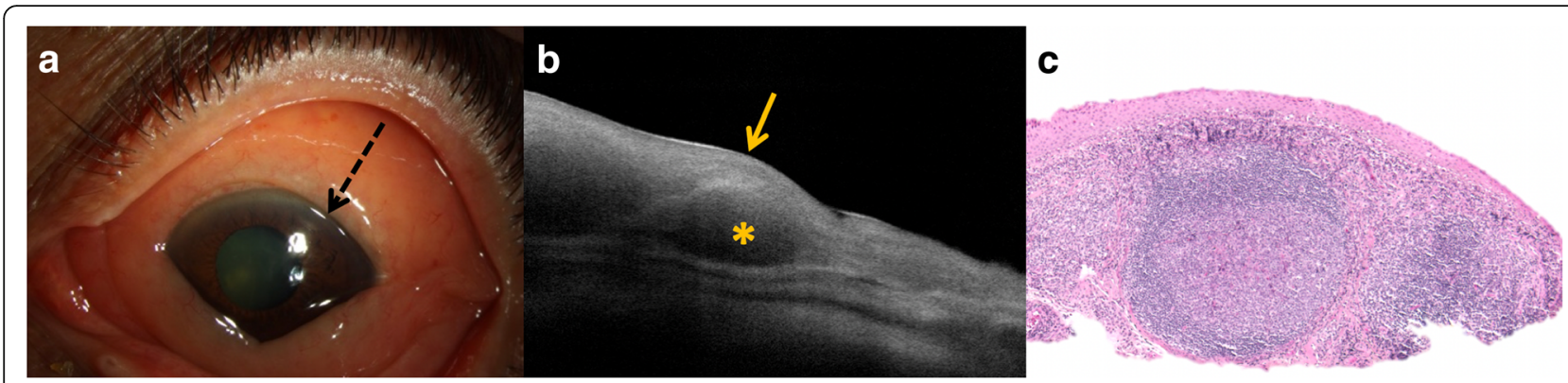

Fig. 3 Clinical, high-resolution optical coherence tomography (HR-OCT), and pathological findings in conjunctival lymphoma. a. Slit lamp image of a diffuse conjunctival infiltrate in the bulbar conjunctiva of left eye $\mathbf{b}$. HR-OCT revealing normal epithelium (arrow) and classic features of conjunctival lymphoma which include a hypo-reflective, homogenous subepithelial mass (*). c. Histopathologic examination discloses intact mucosal epithelium overlying lymphoid follicles present within the substantia propria with surrounding fibrous tissue corresponding to that present in the anterior segment HR-OCT. (Hematoxylin-eosin; original magnification $40 \times$ )

tomography (PET) scan, and bone marrow aspiration and biopsy. The proper management of conjunctival lymphoma is determined by location, extent of periocular involvement, systemic staging of the disease, and general health of the patient.

\section{Clinical staging}

Clinical stage of conjunctival lymphoma is determined by Ann Arbor staging classification and the American Joint Committee on Cancer Tumor, Node, Metastasis (TNM)based staging system for OAL (Table 2) [48-50]. The Ann Arbor staging system is determined by clinical presentation, imaging and laboratory tests, and initial biopsy reports. Each of the four stages is further categorized based on the presence of 'B' symptoms, defined as fever, night sweats, or weight loss of $>10 \%$ body weight over the last 6 months. The TNM system considers several factors that are not addressed by the Ann Arbor staging system. Primary tumor stage, $\mathrm{T}$, is used to categorize the anatomic location of the tumor and tumor spread. Other specific factors designated by the TNM staging system are multiplicity and bilateralism of tumors, lymph node involvement, and distant spread at the time of presentation and diagnosis $[49,51,52]$.

\section{Treatment \\ Treatment of isolated conjunctival lymphoma}

External beam radiation therapy (EBRT) is the gold standard treatment for lymphoma that is isolated to the conjunctiva or to the orbit including the conjunctiva, classified as Ann Arbor Stage I or T1NOM0 or T2NOM0 according to the AJCC criteria. Other less robustly studied

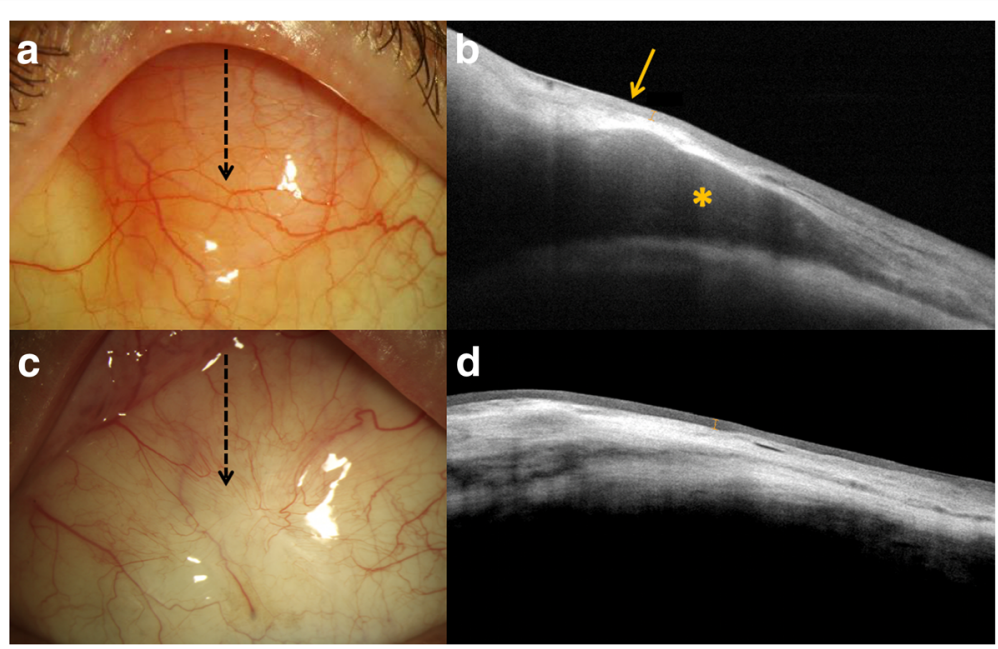

Fig. 4 Clinical and high-resolution optical coherence tomography (HR-OCT) findings of a patient with conjunctival lymphoma before and after external beam radiation (EBRT) a. Slit lamp image of "salmon patch" in the superior bulbar conjunctiva (arrow location of OCT scan). b. HR-OCT revealing normal epithelium (arrow) and a hypo-reflective, homogenous subepithelial mass $\left(^{*}\right)$ consistent with conjunctival lymphoma. c. After confirmation with biopsy and treatment with 20 sessions of EBRT, the tumor resolved (arrow location of OCT scan). d. The HR-OCT post-treatment confirmed the resolution of the tumor 
Table 2 Clinical staging of ocular adnexal lymphoma $(\mathrm{OAL})$

\begin{tabular}{|c|c|c|}
\hline \multirow{10}{*}{$\begin{array}{l}\text { National Cancer } \\
\text { Institute Working } \\
\text { Formulation [48] }\end{array}$} & \multirow[t]{3}{*}{ Low-grade } & Small lymphocytic \\
\hline & & Follicular small cleaved cell \\
\hline & & $\begin{array}{l}\text { Follicular mixed, small cleaved } \\
\text { and large cell }\end{array}$ \\
\hline & \multirow{4}{*}{$\begin{array}{l}\text { Intermediate- } \\
\text { grade }\end{array}$} & Follicular large cell \\
\hline & & Diffuse small cleaved cell \\
\hline & & $\begin{array}{l}\text { Diffuse mixed, small and } \\
\text { large cell }\end{array}$ \\
\hline & & Diffuse large cell \\
\hline & \multirow[t]{3}{*}{ High-grade } & Large cell, immunoblastic \\
\hline & & Lymphoblastic \\
\hline & & Small non-cleaved cell \\
\hline \multirow[t]{5}{*}{$\begin{array}{l}\text { Ann Arbor } \\
\text { Staging [49] }\end{array}$} & Stage I & $\begin{array}{l}\text { Involvement of a single lymph } \\
\text { node region or extralymphatic } \\
\text { site (IE) }\end{array}$ \\
\hline & Stage II & $\begin{array}{l}\text { Involvement of } 2 \text { or more lymph } \\
\text { nodes, lymphatic structures, or } \\
\text { extralymphatic regions alone on } \\
\text { the same side of the } \\
\text { diaphragm (IIE) }\end{array}$ \\
\hline & Stage III & $\begin{array}{l}\text { Involvement of lymph nodes } \\
\text { on both sides of the diaphragm } \\
\text { with localized extralymphatic (IIIE) } \\
\text { or splenic (IIIS) involvement, or } \\
\text { both (IIIES) }\end{array}$ \\
\hline & \multirow[t]{2}{*}{ Stage IV } & $\begin{array}{l}\text { Involvement of one or more } \\
\text { organs or tissues outside the } \\
\text { lymphatic system }\end{array}$ \\
\hline & & $\begin{array}{l}\text { A: Without B symptoms } \\
\text { B: Fever, night sweats, weight } \\
\text { loss of }>10 \% \text { body weight over } \\
\text { the last } 6 \text { months }\end{array}$ \\
\hline \multirow{9}{*}{$\begin{array}{l}\text { TNM Staging } \\
\text { System [50] }\end{array}$} & TO & No evidence of lymphoma \\
\hline & $\mathrm{T} 1$ & $\begin{array}{l}\text { Lymphoma involving the } \\
\text { conjunctiva alone without } \\
\text { orbital involvement }\end{array}$ \\
\hline & T2 & $\begin{array}{l}\text { Lymphoma with orbital } \\
\text { involvement } \pm \text { any conjunctival } \\
\text { involvement }\end{array}$ \\
\hline & T3 & $\begin{array}{l}\text { Lymphoma with preseptal eyelid } \\
\text { involvement } \pm \text { orbital involvement } \pm \\
\text { any conjunctival involvement }\end{array}$ \\
\hline & $\mathrm{T} 4$ & $\begin{array}{l}\text { Orbital adnexal lymphoma } \\
\text { extending beyond orbit to } \\
\text { adjacent structures, such as } \\
\text { bone and brain }\end{array}$ \\
\hline & No & $\begin{array}{l}\text { No evidence of lymph node } \\
\text { involvement }\end{array}$ \\
\hline & N1 & $\begin{array}{l}\text { Involvement of ipsilateral } \\
\text { regional lymph nodes }\end{array}$ \\
\hline & $\mathrm{N} 2$ & $\begin{array}{l}\text { Involvement of contralateral } \\
\text { or bilateral regional lymph } \\
\text { nodes }\end{array}$ \\
\hline & N3 & $\begin{array}{l}\text { Involvement of peripheral } \\
\text { lymph nodes not draining } \\
\text { ocular adnexal region }\end{array}$ \\
\hline
\end{tabular}

Table 2 Clinical staging of ocular adnexal lymphoma (OAL) (Continued)

\begin{tabular}{ll} 
N4 & $\begin{array}{l}\text { Involvement of central } \\
\text { lymph nodes }\end{array}$ \\
& $\begin{array}{l}\text { No evidence of involvement } \\
\text { of other extranodal sites }\end{array}$ \\
M1 & $\begin{array}{l}\text { Lymphomatous involvement } \\
\text { in other organs recorded } \\
\text { either at first diagnosis } \\
\text { or subsequently }\end{array}$ \\
\hline
\end{tabular}

TNM= Tumor, Node, Metastasis

but successful treatment options include local injection of immunotherapy and antibiotic therapy. In cases of bilateral $\mathrm{OAL}$, occasionally systemic treatment is selected over bilateral external beam radiation. Surgical excision alone has shown higher rates of local and systemic recurrence as compared with the treatment options to be detailed below (Table 3) [53, 88]. Very rarely, cases of spontaneous regression of conjunctival disease after excisional biopsy have been reported [63, 89]. A watch-andwait approach may rarely be chosen based on clinician and patient preference/age/health status in cases of unilateral conjunctival lymphoma of indolent histological subtype, but is not recommended due to the possibility of progression of ophthalmic disease as well as the appearance of systemic disease in the future [3, 61, 90-92] (Fig. 5).

External beam radiation therapy EBRT has been considered the standard treatment for low-grade, isolated OALs for the past several decades. Five-year local control rates with radiotherapy alone in the treatment of OAL range from 89 to $100 \%[13,54-57,59,60,64,66,93-97]$. The clinical target volume should include the entire conjunctival surface, from bulbar to the fornices to palpebral conjunctiva, while minimizing radiation to adjacent uninvolved areas of the eye and lacrimal gland. The entire orbit need not be included in the irradiated volume $[5,67$, 98]. A dose range between 20 and 30 Gy is recommended as the primary treatment for indolent subtypes of isolated conjunctival lymphoma [30, 31, 56, 65, 98, 99]. Similarly, for indolent orbital lymphoma, doses of 24 to 25 Gy have been associated with satisfactory resolution of disease and long-term survival rates $[5,66,93,98,100,101]$.

The largest study to date on the use of radiation therapy for lymphoma isolated to the conjunctiva is a Korean study of 121 eyes (79 patients) with a median age at diagnosis of 38 years. Local control after 26 Gy radiation therapy was $98.1 \%$. The 5 -year survival rate was $100 \%$; all but one of the relapsed cases were treated with reradiation therapy. In this study, the radiation was delivered with five 2 Gy fractions per week [60].

Several studies have found associations between the site of disease, tumor grade, or histopathology of the lesion 


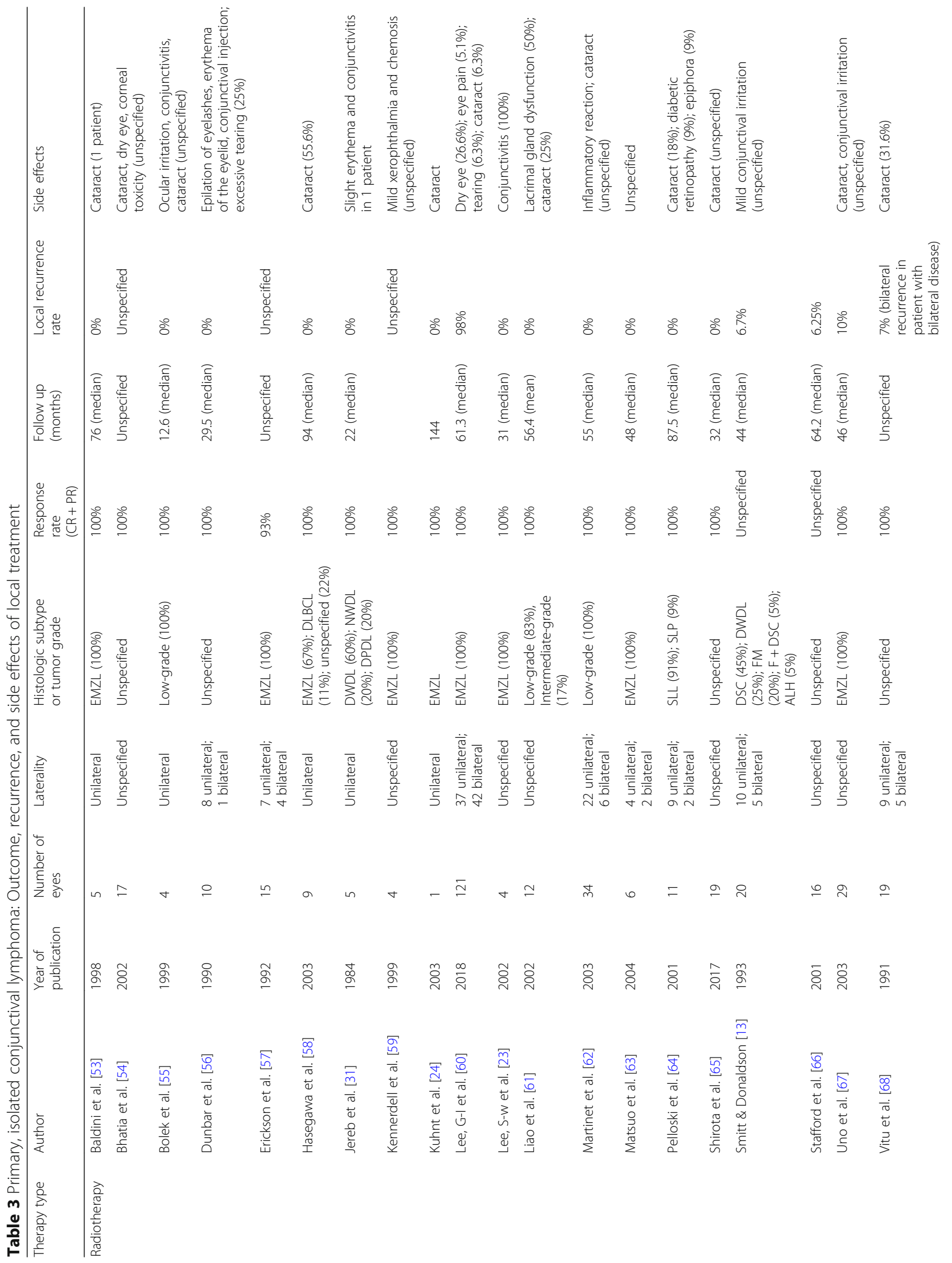




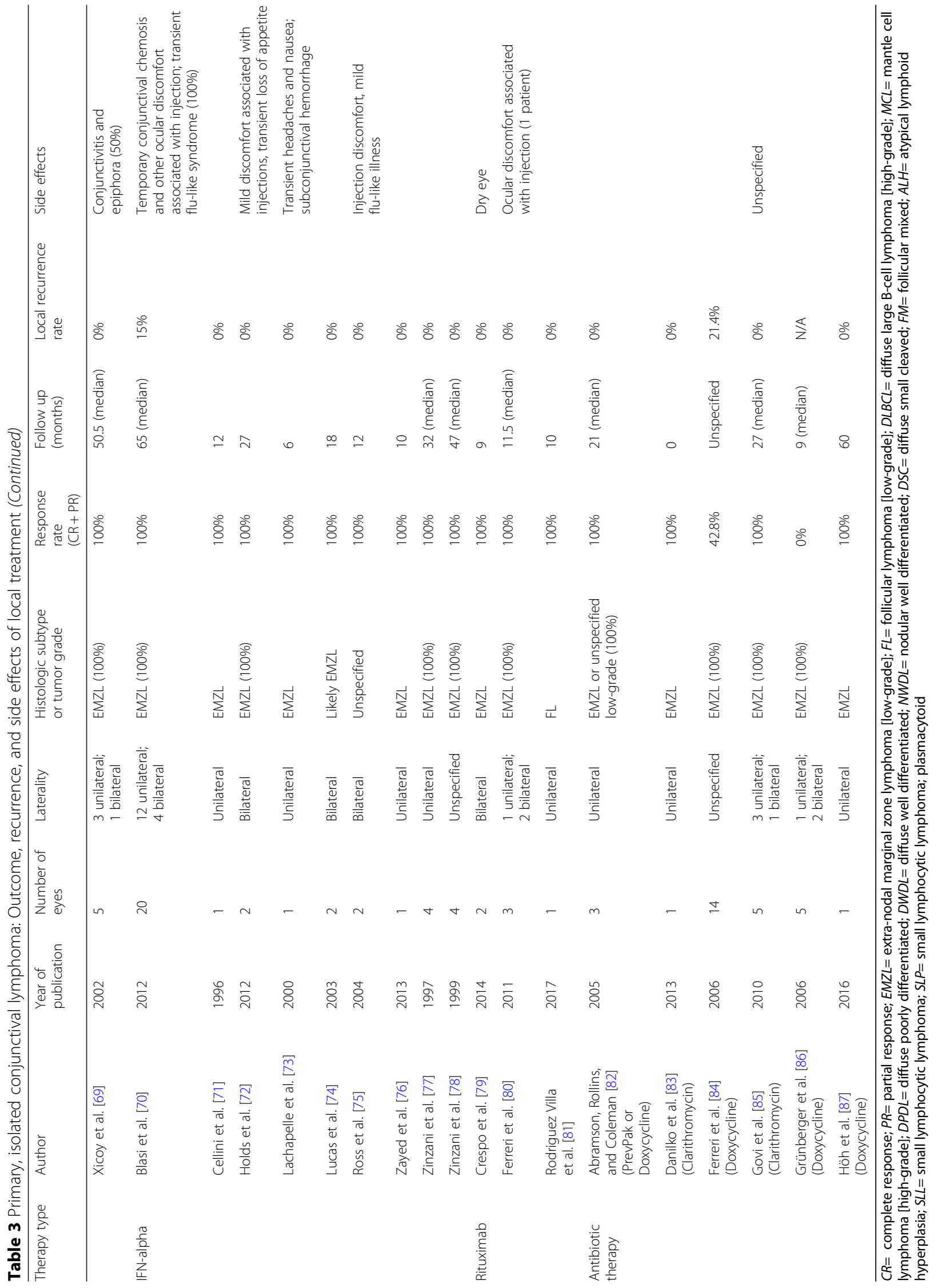




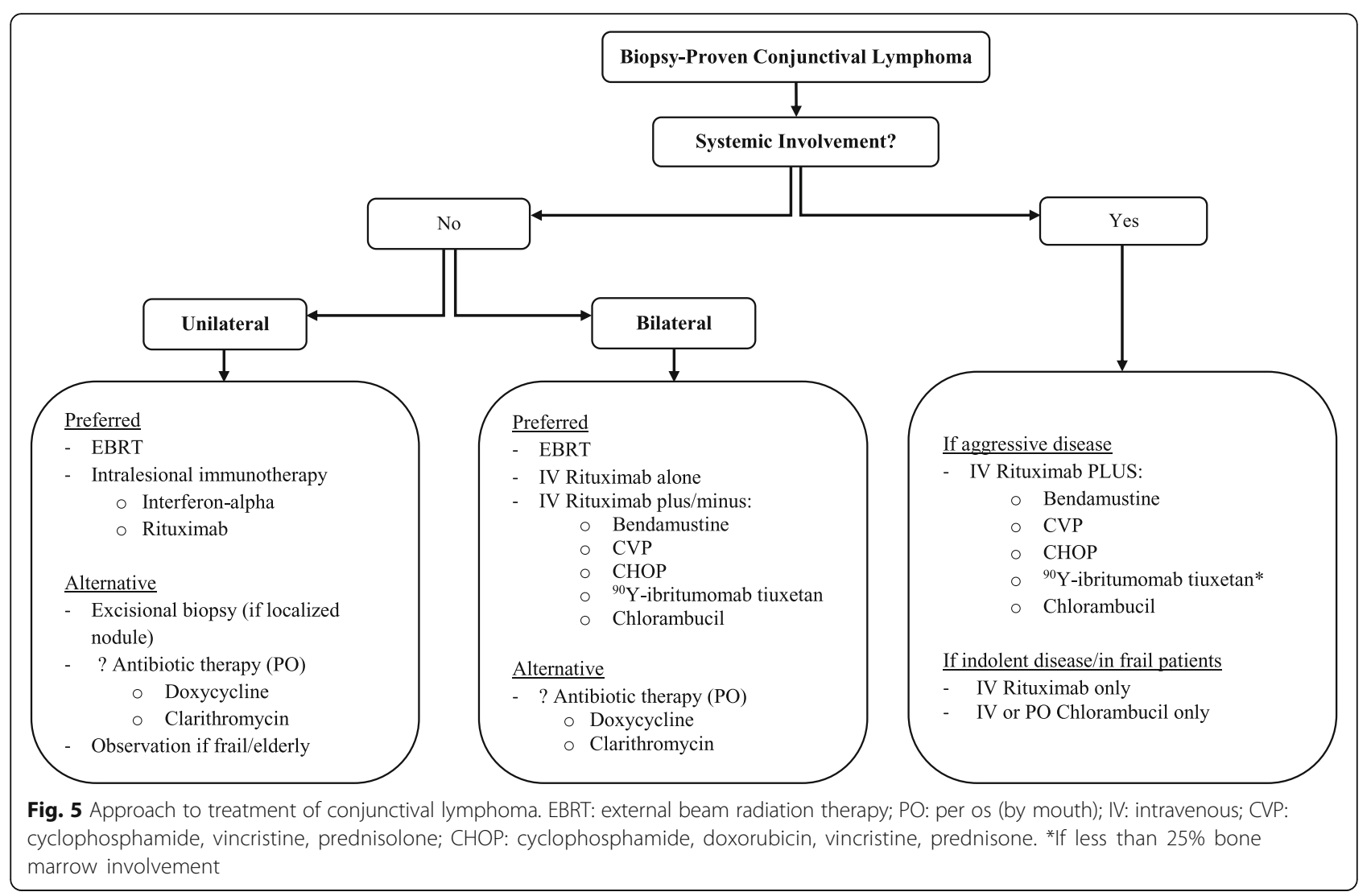

and long-term outcome of EBRT. In one retrospective study, relapse at distant sites after treatment completion was significantly higher in patients with lacrimal and soft tissue disease $(51 \%)$ than in those with only conjunctival lesions (11\%) [93]. Bolek et al. similarly found higher recurrence rates in cases with concomitant orbital adnexal lymphoma as compared to Stage I disease limited to the lid or conjunctiva [55]. Hasegawa et al. reported significantly longer 5- and 10-year overall and relapse-free survival rates of patients with indolent EMZL than in those with DLBCL [58].

Early minor complications of local radiation treatment include eyelid irritation and mild conjunctivitis. Longterm complications, which occur in up to $50 \%$ of patients, include dry eye syndrome (which can be severe), cataract formation, retinopathy, orbital fat tissue atrophy, and corneal ulceration [5, 93, 98, 102]. Lens shielding has been found to reduce the incidence of cataract formation in many studies $[5,13,55,56,67,88,93,98,103]$. Although the exact optimal dose of radiation in the treatment of OAL is subject to debate, doses above 35 Gy have had higher rates of post-treatment complications and morbidity in some studies [5, 93, 98]. In addition to a lower dose, smaller daily fractions may help to reduce radiation toxicity $[49,98]$.
Current literature reports possible therapeutic success with much lower doses of radiation than previously used. A recent retrospective review of 22 patients with EMZL, FL, or MCL of the ocular adnexa who underwent ultra-low-dose EBRT, 4Gy delivered to the orbit(s) in two 2-Gy fractions on two consecutive days, revealed an overall response rate of $100 \%$, after a median time of 3.73 months following treatment. Local control was $75 \%$ after 2 years [101]. Further studies with long-term follow-up are needed.

Immunotherapy Interferon-alpha is a family of cytokines with anti-viral, anti-proliferative, and immunomodulatory functions. Interferons aid in cancer treatment by enhancing the immune response and directly affect tumor cells by increasing transcription of tumor suppressor gene p53, inducing apoptosis, and inhibiting angiogenesis [70]. Cellini et al. first documented the successful use of intralesional interferon-alpha in the treatment of conjunctival lymphoma [71]. Subsequently, its efficacy has largely been examined in case reports and small prospective studies. Interferon-alpha is typically administered as intralesional injections of 1 to 1.5 million international units (IU) in $0.25 \mathrm{~mL}$, repeated three times weekly for a period of 4 to 6 weeks [70-73, 75-78]. Lucas et al. successfully 
treated a patient with bilateral lesions with 10 injections of 10 million IU given over a 4 week period [74]. Blasi et al. conducted the largest study to date on the outcome of intralesional interferon-alpha treatment of conjunctival lymphoma: 19 patients with primary EMZL of the conjunctiva and one patient with conjunctival lymphoma secondary to systemic disease that was in remission were treated with 12 doses of 1.5 million IU followed by another 12-dose course of 1 million IU of interferon-alpha. Local control was $85 \%$ after a median follow-up of 65 months [70].

Local side effects to interferon-alpha include temporary conjunctival chemosis at the site of injection and transient flu-like symptoms including fever, myalgia, and headache that may last for several hours after injection during the initial weeks of treatment [70, 72, $73,75,104]$. In general, interferon-alpha has low toxicity and has not been associated with significant adverse effects in the localized treatment of conjunctival lymphoma.

Rituximab is a chimeric human-rodent monoclonal antibody that targets the surface antigen CD20, which is overexpressed on CD20-positive NHL B cells. Rituximab binding mediates complement-dependent cytotoxicity and antibody-dependent cellular cytotoxicity, and induces cellular apoptosis [102]. It is frequently administered intravenously in the treatment of a variety of systemic B-cell lymphomas, including cases of OAL with bilateral or systemic involvement $[105,106]$. Intralesional rituximab therapy has been used in the treatment of primary B-cell cutaneous lymphoma with equivalent response rates, fewer adverse effects, and lower cost as compared to systemic rituximab treatment [107]. Recent case reports have commented on the efficacy of using intralesional injections in the treatment of relapsed and recurrent OALs [80, 81, 108, 109]. Intralesional rituximab is delivered as four weekly injections of approximately $1.5 \mathrm{~mL}$ followed by six monthly injections of the same, with the aid of topical anesthesia. Reports by Ferreri et al. and Crespo et al. describe recurrent cases of conjunctival EMZL, both unilateral and bilateral, that after undergoing several types of systemic treatment (e.g., IV rituximab, chemotherapy, antibiotic therapy, radiation) were successfully treated with intralesional rituximab without disease progression or recurrence at a range of 9 to 13 months $[79,80]$. Demirci et al. describes a patient with a history of Sjögren syndrome with recurrence of bilateral lacrimal gland EMZL after completion of systemic rituximab therapy. The patient was then treated with intralesional rituximab and remained free from recurrence at 23 and 30 months of follow-up [110]. Rodríguez Villa et al. documented a case of previously untreated unilateral FL of the conjunctiva that resolved with intralesional rituximab [111].
No significant adverse ocular events have been reported secondary to administration of intralesional rituximab in the treatment of OAL. Some patients experience mild pain and local inflammation lasting less than $24 \mathrm{~h}$ after injection [80].

Antibiotic therapy Despite the suspected link between OAL and C. psittaci, antibiotic therapy has been found to have variable efficacy and requires further investigation $[32,86]$. Doxycycline is a well-tolerated therapeutic option that has been most successful when used in geographical regions that are known to have higher rates of C. psittaci infection. Typical dosing of doxycycline is $100 \mathrm{mg}$ twice daily by mouth for 3 or 6 weeks.

In several Korean and Italian studies, doxycycline was shown to be a viable treatment option for T1N0M0 OAL, with two of the largest studies claiming 5-year progression-free survival (PFS) rates of 55 and $60.9 \%$ $[36,84,112-114]$. It has also been successful in smaller case studies in areas not typically associated with C. psittaci infection [82, 87]. Statistically significant improvements in response rate and survival have been associated with localized TNM stage, absence of absolute lymphocytosis, presence of absolute neutropenia, confirmation of C. psittaci infection, and treatment with a double course of doxycycline [84, 113, 114]. Of note, a large Korean retrospective study found conjunctival lymphomas to have superior response rates to doxycycline as compared to non-conjunctival lymphomas $(\mathrm{OR}=11.8,95 \% \mathrm{CI}$, $1.1-122.5 ; P=0.038)$. In addition, the 2 -year time to treatment failure (TTF) was $88 \%$ for conjunctival lymphoma, compared to $64 \%$ for non-conjunctival tumors [113].

The use of clarithromycin in the treatment of extranodal lymphoma has also been explored but reports are scarce $[83,85,115]$. Govi et al. published a study in which the patients with conjunctival disease had a superior response to a six-month course of clarithromycin; local control in these patients was $100 \%$ at a median follow-up time of 27 months [85].

\section{Treatment of conjunctival lymphoma with systemic involvement}

Systemic treatment is reserved for aggressive bilateral disease or conjunctival lymphoma accompanied by active systemic involvement. The recommended treatment for this is intravenous rituximab in combination with chemotherapy or other immunotherapeutic agents (Table 4).

Commonly used chemotherapeutic agents are chlorambucil and combined regimens such as CHOP [89, 92]. Due to the high risk of distant relapse associated with local radiation used in the treatment of intermediate and high-grade conjunctival lymphoma, adjuvant chemotherapy is recommended in complicated cases or aggressive 


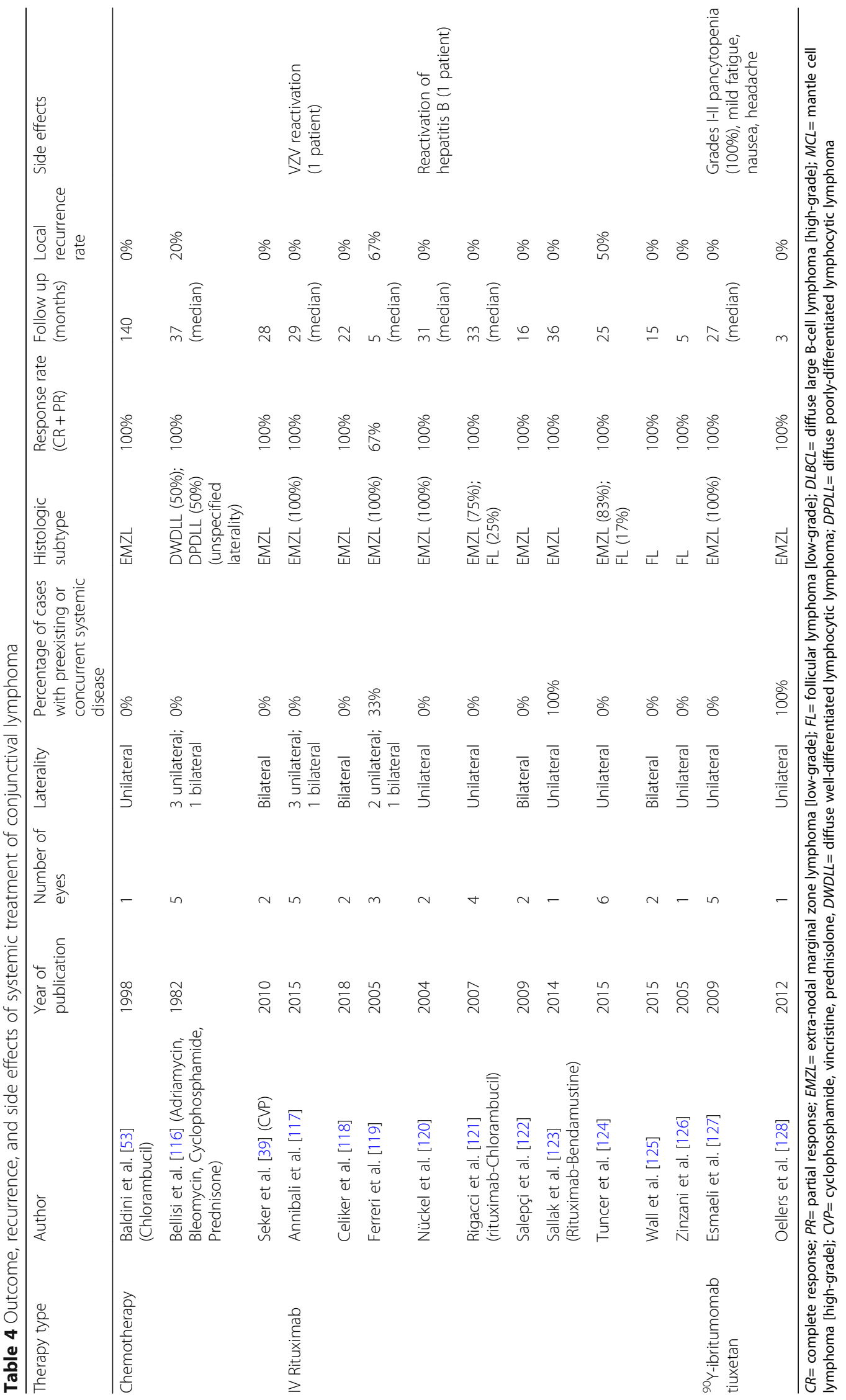


histological subtypes (MCL, DLBCL, T-cell lymphoma) [13, $55,89,99,129,130]$.

Chemotherapy Chemotherapy can be used as an adjunct to local treatment or as the sole therapy for OAL. It is the treatment of choice, typically in combination with rituximab, in cases of systemic disease, resistance to radiation, or contraindication of radiation therapy [89] (Fig. 5). Data on the use of chemotherapy in patients with conjunctival lymphoma is limited. When used as a single agent or as part of combined therapy, it has produced varied results $[53,88,103,116,131,132]$.

Bendamustine is a chemotherapeutic drug with alkylating and antimetabolic properties. In 2008, it was approved for the treatment of both indolent and aggressive B-cell NHL after it was found to successfully treat NHL that had relapsed after primary treatment with rituximab or a rituximab-containing regimen in three independent phase II trials $[133,134]$. Although further studies are needed to evaluate its treatment of OAL or conjunctival lymphoma specifically, there is robust evidence that bendamustine demonstrates excellent outcomes as both a single agent and in combination with rituximab [123, 133-136].

Chlorambucil, which is frequently used in combination chemotherapy regimens such as CVP (cyclophosphamide, vincristine, prednisolone) and $\mathrm{CHOP}$ (cyclophosphamide, doxorubicin, vincristine, prednisone), has a highly favorable toxicity profile. Complete response to chlorambucil has been observed in $67-100 \%$ of patients with OAL, but local relapse occurs in up to $29 \%$ of cases [137]. A study on OAL by Ben Simon et al. showed an overall response rate of $100 \%$ after an average of 4 courses of oral chlorambucil (average total dose $600 \mathrm{mg}$ ). Four patients (12\%) had recurrence of disease; one was a case of local orbital recurrence while the other three developed extraorbital lymphoma disease. One of the relapsed patients died following a transformation to DLBCL [138]. A Korean study on EMZL of the ocular adnexa also reported an overall response rate of $100 \%$ to CVP. Seven cases (33\%) showed disease recurrence at a median of 58 months after treatment, five local and two at extraorbital sites. The five cases of local failure obtained complete response after treatment with radiation therapy. Toxic effects associated with CVP in this study were neutropenia, anemia, elevated alanine aminotransferase, and peripheral neuropathy [139].

Immunotherapy As discussed above, rituximab has cytotoxic effects on CD20-positive B cells and is the most commonly used immunotherapeutic agent for the treatment of lymphoma [102]. It is typically used in conjunction with other therapy in the treatment of conjunctival lymphoma with systemic involvement or with risk factors for systemic involvement. Typical treatment with single-agent rituximab consists of four to six consecutive weekly IV infusions at a dose of $375 \mathrm{mg} / \mathrm{m}^{2}$. It is very well tolerated. Most case reports in which rituximab was delivered in this manner in the treatment of newly diagnosed OAL revealed a $100 \%$ overall response rate $[117-119,122$, $125,126,140]$. However, a Ferreri et al. study calls into question the long-term efficacy of this treatment. In a 2005 study, four out of five recently diagnosed patients had local relapse at a median of 20 months after treatment. One of these patients also had systemic relapse with involvement of axillary lymph nodes and subcutaneous nodules [118]. Although follow-up was limited at a median of 29 months, Annibali et al. showed successful outcome maintenance in their study on six patients with EMZL-type OAL with an extended treatment course. Four patients (67\%) obtained complete response and two patients (33\%) obtained partial response. None of the patients had disease progression or recurrence [117]. Celiker et al. reported a case of bilateral conjunctival EMZL in which partial response was obtained after 6 cycles and complete response after 10 . There was no recurrence after 22 months of follow-up [119]. These results contrast with those from a study by Tuncer et al., which revealed a complete response in only 4 of 11 reviewed cases of primary OAL. The remaining patients required additional radiotherapy due to partial response or recurrence of disease. In this study, though, of the six patients whose disease was isolated to the conjunctiva (5 EMZL and $1 \mathrm{FL}$ ), five achieved complete response and remained free of local disease for a median follow-up of 25 months [124].

Sullivan et al. demonstrated the usefulness of systemic rituximab treatment in OAL patients with preexisting or concurrent systemic disease. In this study, seven of eight patients responded to rituximab therapy. One of those had relapse of orbital disease at 26 months while the rest remained free of disease recurrence at a median of 17.5 months of follow-up. The eighth patient did not respond to rituximab treatment and passed away after progression of systemic disease [106]. Other case reports have also demonstrated long-term efficacy of systemic rituximab in the treatment of recurrent conjunctival disease [120, 122].

Rituximab is theorized to sensitize B cells to the effects of systemic treatment, and combination therapy with rituximab and conventional chemotherapy have been associated with higher response rates than chemotherapy alone in the treatment of NHL $[102,124]$. Rigacci et al. used a combination of rituximab and chlorambucil in the treatment of nine newly diagnosed OAL patients, eight with EMZL and one with FL. Four of the patients had disease localized to the conjunctiva. Response rate was 100\%; after a median follow-up of 25 months, no ocular toxicity nor disease progression was reported [121]. A larger, randomized study on patients with 
systemic MALT lymphoma (not of the ocular adnexa) showed patients who were treated with a combination of chlorambucil and rituximab had a significantly better median progression-free survival $(p=0.0119)$ than those patients who were treated with chlorambucil or rituximab alone [141].

Radioimmunotherapy Radioimmunotherapy, in which monoclonal antibodies are used to deliver radioisotopes to the site of disease, has shown a better response than rituximab alone in some studies [142]. Yttrium 90labeled ibritumomab tiuxetan $\left(\right.$ Zevalin $\left.^{\circ}\right)$ is a radiolabeled anti-CD20 monoclonal antibody that is used in the treatment of refractory or relapsed low-grade B-cell NHL. It uses pure $\beta$ emission to kill both target cells and nearby cells that may not express the antigen receptors via a bystander effect. This mechanism works independently of the host immune system. As is true with rituximab, ${ }^{90}$ Y-ibritumomab tiuxetan is well tolerated in patients. Transient pancytopenia often occurs in patients during the first 3 months following drug administration, sometimes necessitating transfusions. The estimated absorbed radiation to orbital soft tissues with ${ }^{90}$ Y-ibritumomab tiuxetan use is less than 3 Gy. Its use has not resulted in any of the ocular toxicities associated with external beam radiation treatment [102]. Other common side effects include fatigue, nausea, and headache [127]. Studies on ${ }^{90}$ Y-ibritumomab tiuxetan use in conjunctival and OAL are limited but have shown excellent response rates $[127,128,142]$. An established protocol by Esmaeli et al. dictates a treatment course that begins with intravenous administration of rituximab $250 \mathrm{mg} / \mathrm{m}^{2}$ prior to Indium total-body imaging. One week after this, patients are given a second dose of rituximab $250 \mathrm{mg} / \mathrm{m}^{2} \mathrm{IV}$, followed by ${ }^{90}$ Y-ibritumomab tiuxetan. Typically, patients with a platelet count of $100,000-149,000 / \mathrm{mm}^{3}$ are given $0.3 \mathrm{mCi} / \mathrm{kg}{ }^{90} \mathrm{Y}$-ibritumomab tiuxetan, while patients with a platelet count above $150,000 / \mathrm{mm}^{3}$ are given a dose of $0.4 \mathrm{mCi} / \mathrm{kg}$ [127] (Fig. 5).

\section{F. Prognosis}

Ocular adnexal lymphoma has an overall 5-year survival rate ranging between 50 and $94 \%$, depending on the grade of histologic subtype, TNM stage at diagnosis, and age of the patient [131]. Conjunctival lymphoma in particular has a good prognosis, with some studies demonstrating a $90 \%$ progression-or-recurrence-free population after 1 year of follow-up [3, 30].

The most important prognostic factor in conjunctival lymphoma is histological subtype of the lesion. Isolated cases of low-grade EMZL and FL are associated with the best outcome after treatment $[3,20,49,54,58,102$, 143]. A 2016 retrospective study by Kierkegaard et al. on 263 patients with conjunctival lymphoma found the following 5-year survival rates: EMZL 97.0\%, FL 82.0\%, DLBCL 55.0\%, and MCL 9.0\%. In this study, most patients with localized disease were treated with EBRT with or without chemotherapy [144]. A 2018 study on EMZL of the ocular adnexa revealed patients with conjunctival disease to have a $66 \% 5$-year progression-free survival and a $76 \%$ overall 5-year survival rate. Progression-free survival in this study was higher in conjunctival sites as compared to lacrimal gland and eyelid (50\%), but lower than orbital sites (74\%) [145].

Other clinical, laboratory, and various tumor biomarkers have been associated with prognostic effect. Established negative prognostic factors in the outcome of OAL include: age greater than $60-64$ years [16, 62, 88, 146, 147], elevated serum LDH level [143, 147, 148], and increased blast percentage with positivity for tumor suppressor p53, and p21 and pRB positivity [26, 146]. Ferreri et al. reported that OAL patients with concomitant hepatitis $C$ infection were more likely to have aggressive disease with lymph node and other extranodal organ involvement, higher relapse rates after treatment, and worse progression-free survival [37]. Coupland et al. investigated the prognostic value of cell-cycle associated markers in disease-free survival and lymphoma-related death. Tumor markers associated with higher risk for disseminated disease at some point during the observed clinical course included the lymphoma-associated transcription factor BCL-6, MUM1/ IRF4 (multiple myeloma oncogene-1/interferon regulatory factor 4), and MIB1/Ki-67, a marker of cellular proliferation [146].

Advanced stage at the time of diagnosis also correlates with worse long-term prognosis of OAL [14, 20, 55, 62, 88, 99, 129, 143, 146, 147]. Lymphoma classified as Ann Arbor stage II-IV, indicating disease that has involvement beyond the extranodal site, is associated with earlier disease progression and/or relapse after initial treatment [16, 148]. One factor postulated to predict risk for disseminated disease is bilaterality $[15,67,68,102,129,149]$. A 2001 Shields et al. analysis of 117 patients with lymphoid tumors of the conjunctiva found that $17 \%$ of patients with unilateral conjunctival involvement at the time of diagnosis had systemic lymphoma, while this number rose to $47 \%$ for those with bilateral conjunctival lesions [15]. Other studies have found no correlation between bilaterality of disease and worse prognosis [69].

Variation on outcome based on the site of OAL is debated. Many studies have found significantly better outcomes, including progression-free survival and overall survival, in patients with conjunctival lymphoma as compared to other ocular adnexal sites [62, 145, 148, 150]. However, other reviews have not found anatomic location to be an independent risk factor for disease-free survival or development of systemic disease [13, 49, 65, 67, 94, 146]. 


\section{Conclusion}

Lymphoma is among the most common malignant conjunctival tumor. As the symptoms are often minimal, it is imperative for the general ophthalmologist to be alert for the characteristic "salmon patch" appearance of these neoplasms or to suspect lymphoma in individuals with unexplained chronic follicular conjunctivitis. Diagnosis is established via surgical biopsy with proper fresh tissue immunohistochemical studies. New imaging techniques with high resolution OCT can also help identify possible lymphoproliferative lesions as well as assist in the ongoing clinical evaluation during and after treatment. Systemic work-up and staging are critical to formulating the correct treatment plan. Both local and systemic treatments are available. The ophthalmologist should remain active in the management of possible ocular complications during lymphoma treatment. Long-term follow-up is necessary as systemic lymphoma may develop after many years.

\section{Acknowledgements}

None.

\section{Authors' contributions}

RT was a major contributor in writing the manuscript. AG was a contributor in review of the manuscript. SD participated in the images and writing. CK was involved in concept, design, development and major review of the manuscript. All authors read and approved the final manuscript.

\section{Funding}

NIH Center Core Grant P30EY014801, Research to Prevent Blindness Unrestricted Grant, The Ronald and Alicia Lepke Grant, The Lee and Claire Hager Grant, The Jose Ferreira de Melo Grant, The Robert Baer Family Grant, The Emilyn Page and Mark Feldberg Grant, The Ted and Michele Kaplan Grant, The Richard Azar Family Grant (institutional grants), and the Florida Lions Eye Bank. (institutional grants).

\section{Availability of data and materials}

Not applicable.

\section{Ethics approval and consent to participate}

Not applicable.

\section{Consent for publication}

Not applicable.

\section{Competing interests}

The authors declare that they have no competing interests.

Received: 1 March 2019 Accepted: 15 June 2019

Published online: 27 July 2019

\section{References}

1. Zucca E, Roggero E, Bertoni F, Cavalli F. Primary extranodal non-Hodgkin's lymphomas. Part 1: Gastrointestinal, cutaneous and genitourinary lymphomas. Ann Oncol. 1997:8:727-37.

2. Vannata B, Zucca E. Primary extranodal B-cell lymphoma: current concepts and treatment strategies. Chin Clin Oncol. 2015;4(1):10

3. Kirkegaard MM, Coupland SE, Prause JU, Heegaard S. Malignant lymphoma of the conjunctiva. Surv Ophthalmol. 2015;60(5):444-58.

4. Dalvin LA, Salomão DR, Patel SV. Population-based incidence of conjunctival tumours in Olmsted County, Minnesota. Br J Ophthalmol. 2018;102(12):1728-34.

5. Sassone M, Ponzoni M, Ferreri AJ. Ocular adnexal marginal zone lymphoma: Clinical presentation, pathogenesis, diagnosis, prognosis, and treatment. Best Pract Res Clin Haematol. 2017;30(1-2):118-30.
6. Rasmussen PK, Coupland SE, Finger PT, Graue GF, Grossniklaus HE, Honavar SG, et al. Ocular adnexal follicular lymphoma: a multicenter international study. JAMA Ophthalmol. 2014;132(7):851-8.

7. Rubinstein TJ, Aziz HA, Bellerive C, Sires BS, Hing AW, Habermehl G, et al. Ocular/adnexal lymphoma: dissimilar to systemic lymphoma. Surv Ophthalmol. 2018;63(3):381-8.

8. Nam SW, Woo KI, Kim YD. Characteristics of primary extranodal marginal zone B-cell lymphoma in Korea: conjunctiva versus other ocular adnexa. Br J Ophthalmol. 2018;102(4):502-8.

9. Lyons LJ, Vrcek I, Somogyi M, Taheri K, Admirand JH, Chexal S, et al. Natural killer/T-cell lymphoma invading the orbit and globe. Proc (Bayl Univ Med Cent). 2017;30(4):447-9.

10. Kiratli H, Uzun S, Yeşilirmak A, Ayhan AS, Soylemezoğlu F. Conjunctival extranodal natural killer/T-cell lymphoma, nasal type. Cornea. 2015;34(6):710-2

11. Charles NC, Liu CZ, Belinsky I, Patel P. Extranodal natural killer/T-cell lymphoma masquerading as conjunctivitis. Can J Ophthalmol. 2014; 49(4):e87-90.

12. Coupland SE, Foss HD, Assaf C, Auw-Haedrich C, Anastassiou G, Anagnostopoulos I, et al. T-cell and T/natural killer-cell lymphomas involving ocular and ocular adnexal tissues: a clinicopathologic,

immunohistochemical, and molecular study of seven cases. Ophthalmology. 1999;106(11):2109-20

13. Smitt MC, Donaldson SS. Radiotherapy is successful treatment for orbital lymphoma. Int J Radiat Oncol Biol Phys. 1993;26(1):59-66.

14. Coupland SE, Krause L, Delecluse HJ, Anagnostopoulos I, Foss HD, Hummel $\mathrm{M}$, et al. Lymphoproliferative lesions of the ocular adnexa. Analysis of 112 cases. Ophthalmology. 1998;105(8):1430-41.

15. Shields CL, Shields JA, Carvalho C, Rundle P, Smith AF. Conjunctival lymphoid tumors: clinical analysis of 117 cases and relationship to systemic lymphoma. Ophthalmology. 2001;108(5):979-84.

16. Meunier J, Lumbroso-Le Rouïc L, Dendale R, Vincent-Salomon A, Asselain B, Arnaud $\mathrm{P}$, et al. Conjunctival low-grade non-Hodgkin's lymphoma: a large single-center study of initial characteristics, natural history and prognostic factors. Leuk Lymphoma. 2006:47(7):1295-305.

17. Rosado MF, Byrne GE Jr, Ding F, Fields KA, Ruiz P, Dubovy SR, et al. Ocular adnexal lymphoma: a clinicopathologic study of a large cohort of patients with no evidence for an association with chlamydia psittaci. Blood. 2006;107(2):467-72

18. Stefanovic A, Lossos IS. Extranodal marginal zone lymphoma of the ocular adnexa. Blood. 2009:114(3):501-10.

19. Mannami T, Yoshino T, Oshima K, Takase S, Kondo E, Ohara N, et al. Clinical, histopathological, and immunogenetic analysis of ocular adnexal lymphoproliferative disorders: characterization of MALT lymphoma and reactive lymphoid hyperplasia. Mod Pathol. 2001;14(7):641-9.

20. Jenkins C, Rose GE, Bunce C, Wright JE, Cree IA, Plowman N, et al. Histological features of ocular adnexal lymphoma (REAL classification) and their association with patient morbidity and survival. $\mathrm{Br} J$ Ophthalmol. 2000;84(8):907-13.

21. Portell CA, Aronow ME, Rybicki LA, Macklis R, Singh AD, Sweetenham JW. Clinical characteristics of 95 patients with ocular adnexal and uveal lymphoma: treatment outcomes in extranodal marginal zone subtype. Clin Lymphoma Myeloma Leuk. 2014;14(3):203-10.

22. Ferry JA, Fung CY, Zukerberg L, Lucarelli MJ, Hasserjian RP, Preffer Fl, et al. Lymphoma of the ocular adnexa: A study of 353 cases. Am J Surg Pathol. 2007:31(2):170-84

23. Lee SW, Suh CO, Kim GE, Yang WI, Lee SY, Hahn JS, et al. Role of radiotherapy for primary orbital lymphoma. Am J Clin Oncol. 2002; 25(3):261-5.

24. Kuhnt $T$, Wollschläger $B$, Bloching $M$, Krause U, Dunst J. Extranodal nonHodgkin's lymphoma of MALT-type stage I. A case report. Strahlenther Onkol. 2003;179(6):396-400.

25. Andrew NH, Coupland SE, Pirbhai A, Selva D. Lymphoid hyperplasia of the orbit and ocular adnexa: A clinical pathologic review. Surv Ophthalmol. 2016:61(6):778-90

26. Annibali O, Sabatino F, Mantelli F, Olimpieri OM, Bonini S, Avvisati G. Review article: Mucosa-associated lymphoid tissue (MALT)-type lymphoma of ocular adnexa. Biology and treatment. Crit Rev Oncol Hematol. 2016;100:37-45.

27. Shields CL, Chien JL, Surakiatchanukul T, Sioufi K, Lally SE, Shields JA. Conjunctival tumors: Review of clinical features, risks, biomarkers, and outcomes--The 2017 J. Donald M. Gass Lecture. Asia Pac J Ophthalmol (Phila). 2017;6(2):109-20 
28. Fukuhara J, Kase S, Ishijima K, Noda M, Ishida S. Conjunctival lymphoproliferative disorder. Ophthalmology. 2011;118(2):423.e1-2.

29. Fukuhara J, Kase S, Noda M, Ishijima K, Yamamoto T, Ishida S. Conjunctival lymphoma arising from reactive lymphoid hyperplasia. World J Surg Oncol. 2012;10:194.

30. Richards H, Ramsden C, Naidoo R, Yvon C, Jacob E, Mohamedbhai S. Ocular adnexal lymphomas: a review. Expert Review of Ophthalmology. 2017;12(2):133-48

31. Jereb B, Lee $H$, Jakobiec FA, Kutcher J. Radiation therapy of conjunctival and orbital lymphoid tumors. Int J Radiat Oncol Biol Phys. 1984;10(7):1013-9.

32. Husain A, Roberts D, Pro B, McLaughlin P, Esmaeli B. Meta-analyses of the association between Chlamydia psittaci and ocular adnexal lymphoma and the response of ocular adnexal lymphoma to antibiotics. Cancer. 2007; 110(4):809-15.

33. Ferreri AJ, Guidoboni M, Ponzoni M, De Conciliis C, Dell'Oro S, Fleischhaue $\mathrm{K}$, et al. Evidence for an association between Chlamydia psittaci and ocular adnexal lymphomas. J Nati Cancer Inst. 2004;96(8):586-94.

34. Yoo C, Ryu MH, Huh J, Park JH, Kang HJ, Ahn HS, et al. Chlamydia psittaci infection and clinicopathologic analysisof ocular adnexal lymphomas in Korea. Am J Hematol. 2007;82(9):821-3.

35. Aigelsreiter A, Leitner E, Deutsch AJ, Kessler HH, Stelzl E, Beham-Schmid C, et al. Chlamydia psittaci in MALT lymphomas of ocular adnexals: the Austrian experience. Leuk Res. 2008;32(8):1292-4.

36. Ferreri AJ, Govi S, Pasini E, Mappa S, Bertoni F, Zaja F, et al. Chlamydophila psittaci eradication with doxycycline as first-line targeted therapy for ocular adnexae lymphoma: final results of an international phase II trial. J Clin Oncol. 2012;30(24):2988-94.

37. Ferreri A, Viale E, Guidoboni M, Resti AG, De Conciliis C, Politi L, et al. Clinical implications of hepatitis C virus infection in MALT-type lymphoma of the ocular adnexa. Ann Oncol. 2006:17(5):769-72.

38. Nanji AA, Mercado C, Galor A, Dubovy S, Karp CL. Updates in ocular surface tumor diagnostics. Int Ophthalmol Clin. 2017:57(3):47-62.

39. Seker M, Ozdemir B, Bilici A, Ustaalioğlu BB, Sonmez B, Yilmaz BE, et al. Bilateral conjunctival MALT Iymphoma mimicking chronic conjunctivitis. Onkologie. 2010;33:317-20.

40. Shields CL, Alset AE, Boal NS, Casey MG, Knapp AN, Sugarman JA, et al. Conjunctival tumors in 5002 cases. Comparative analysis of benign versus malignant counterparts. The 2016 James D. Allen Lecture. Am J Ophthalmol. 2017:173:106-33.

41. Shields CL, Demirci H, Karatza E, Shields JA. Clinical survey of 1643 melanocytic and nonmelanocytic conjunctival tumors. Ophthalmology. 2004;111(9):1747-54

42. Ferreri A, Dolcetti R, Du MQ, Doglioni C, Resti AG, Politi LS, et al. Ocular adnexal MALT lymphoma: an intriguing model for antigen-driven lymphomagenesis and microbial-targeted therapy. Ann Oncol. 2008;19(5):835-46.

43. Shousha MA, Karp CL, Canto AP, Hodson K, Oellers P, Kao AA, et al. Diagnosis of ocular surface lesions using ultra-high-resolution optical coherence tomography. Ophthalmology. 2013;120(5):883-91.

44. Shousha MA, Karp CL, Perez VL, Hoffmann R, Ventura R, Chang V, et al. Diagnosis and management of conjunctival and corneal intraepithelial neoplasia using ultra high-resolution optical coherence tomography. Ophthalmology. 2011;118(8):1531-7.

45. Nanji AA, Sayyad FE, Galor A, Dubovy SR, Karp CL. High-resolution optical coherence tomography as an adjunctive tool in the diagnosis of corneal and conjunctival pathology. Ocul Surf. 2015;13(3):226-35.

46. Yim M, Galor A, Nanji A, Joag M, Palioura S, Feuer W, et al. Ability of novice clinicians to interpret high-resolution optical coherence tomography for ocular surface lesions. Can J Ophthalmol. 2018;53(2):150-4.

47. Shields $\mathrm{CL}$, Shields JA. Tumors of the conjunctiva and cornea. Surv Ophthalmol. 2004:49(1):3-24

48. The Non-Hodgkin's Lymphoma Pathologic Classification Project. National Cancer Institute sponsored study of classification of non- Hodgkin's lymphomas: summary and description of a working formulation for clinical usage. Cancer. 1982:49:2112-35.

49. Graue GF, Finger PT, Maher E, Della Rocca D, Della Rocca R, Lelli GJ Jr, et al. Ocular adnexal lymphoma staging and treatment: American Join Committee on Cancer versus Ann Arbor. Eur J Ophthalmol. 2013;23(3): 344-55.

50. Heegaard S, Chevez-Barrios P, White VA, Coupland SE, Finger PT. The AJCC TNM Cancer Staging Manual, Eighth Edition: Ocular adnexal lymphoma. In: Amin MB, Edge S, Greene F, Byrd DR, Brookland RK, Washington MK, et al., editors. The AJCC TNM Cancer Staging Manual, 8th edition. New York: Springer Publishing Company; 2017. p. 849-54.

51. Coupland SE, White VA, Rootman J, Damato B, Finger PT. A TNM-based clinical staging system of ocular adnexal lymphomas. Arch Pathol Lab Med. 2009:133:1262-7.

52. Rath S, Connors JM, Dolman PJ, Rootman J, Rootman DB, White VA. Comparison of American Joint Committee on Cancer TNM-based staging system (7th edition) and Ann Arbor classification for predicting outcome in ocular adnexal lymphoma. Orbit. 2014;33(1):23-8.

53. Baldini L, Blini M, Guffanti A, Fossati V, Colombi M, La Targia ML, et al. Treatment and prognosis in a series of primary extranodal lymphomas of the ocular adnexa. Ann Oncol. 1998;9(7):779-81.

54. Bhatia S, Paulino AC, Buatti JM, Mayr NA, Wen BC. Curative radiotherapy for primary orbital lymphoma. Int J Radiat Oncol Biol Phys. 2002;54(3):818-23.

55. Bolek TW, Moyses HM, Marcus RB Jr, Gorden L 3rd, Maiese RL, Almasri NM et al. Radiotherapy in the management of orbital lymphoma. Int J Radiat Oncol Biol Phys. 1999:44(1):31-6.

56. Dunbar SF, Linggood RM, Doppke KP, Duby A, Wang CC. Conjunctival lymphoma: results and treatment with a single anterior electron field. A lens sparing approach. Int J Radiat Oncol Biol Phys. 1990;19(2): 249-57.

57. Erickson BA, Harris GJ, Enke CA, Murray KJ, Massaro BM, Hanson GA, et al. Periocular lymphoproliferative diseases: natural history, prognostic factors, and treatment. Radiology. 1992;185(1):63-70.

58. Hasegawa M, Kojima M, Shioya M, Tamaki Y, Saitoh J, Sakurai H, et al. Treatment results of radiotherapy for malignant lymphoma of the orbit and histopathologic review according to the WHO classification. Int J Radiat Oncol Biol Phys. 2003;57(1):172-6.

59. Kennerdell JS, Flores NE, Hartsock RJ. Low-dose radiotherapy for lymphoid lesions of the orbit and ocular adnexa. Ophthalmic Plast Reconstr Surg. 1999;15(2):129-33

60. Lee Gl, Oh D, Kim WS, Kim SJ, Ko YH, Woo Kl, et al. Low-dose radiation therapy for primary conjunctival marginal zone B-cell lymphoma. Cancer Res Treat. 2018;50(2):575-81.

61. Liao SL, Kao SC, Hou PK, Chen MS. Results of radiotherapy for orbital and adnexal lymphoma. Orbit. 2002;21(2):117-23.

62. Martinet S, Ozsahin M, Belkacémi Y, Landmann C, Poortmans P, Oehlere C, et al. Outcome and prognostic factors in orbital lymphoma: a Rare Cancer Network study on 90 consecutive patients treated with radiotherapy. Int J Radiat Oncol Biol Phys. 2003;55(4):892-8.

63. Matsuo T, Yoshino T. Long-term follow-up results of observation or radiation for conjunctival malignant lymphoma. Ophthalmology. 2004; 111(6):1233-7.

64. Pelloski CE, Wilder RB, Ha CS, Hess MA, Cabanillas FF, Cox JD. Clinical stage IEA-IIEA orbital lymphomas: outcomes in the era of modern staging and treatment. Radiother Oncol. 2001;59(2):145-51.

65. Shirota N, Nakayama H, Shiraishi S, Usui Y, Kimura K, Sanada T, et al. Target volume dose and clinical outcome in radiotherapy for primary marginal zone lymphoma of the ocular adnexa. Mol Clin Oncol. 2017:6: 833-8.

66. Stafford SL, Kozelsky TF, Garrity JA, Kurtin PJ, Leavitt JA, Martenson JA, et al. Orbital lymphoma: radiotherapy outcome and complications. Radiother Oncol. 2001:59:139-44.

67. Uno T, Isobe K, Shikama N, Nishikawa A, Oguchi M, Ueno N, et al. Radiotherapy for extranodal, marginal zone, B-cell lymphoma of mucosa-associated lymphoid tissue originating in the ocular adnexa. Cancer. 2003;98(4):865-71.

68. Vitu L, Girinsky T, Briot E, Cosset JM. Electron beam irradiation of conjunctival lymphomas. Int J Radiat Oncol Biol Phys. 1991;21(4):1107-8.

69. Xicoy B, Ribera JM, Arellano A, Mate JL, Millá F, Feliu E. Effectiveness of local radiotherapy in primary extranodal marginal zone B-cell lymphoma of MALT or MALT lymphoma of conjunctiva: study of four cases. Leuk Lymphoma. 2002;43(10):1975-7.

70. Blasi MA, Tiberti AC, Valente P, Laguardia M, Sammarco MG, Balestrazzi A, et al. Intralesional interferon- a for conjunctival mucosa-associated lymphoid tissue lymphoma. Ophthalmology. 2012;119(3):494-500.

71. Cellini M, Possati GL, Puddu P, Caramazza R. Interferon alpha in the therapy of conjunctival lymphoma in an HIV+ patient. Eur J Ophthalmol. 1996:6(4):475-7.

72. Holds J, Buchanan A, Hanson R. Intralesional interferon-a for the treatment of bilateral conjunctival mucosa-associated lymphoid tissue lymphoma. Pedatric Blood Cancer. 2012;59(1):176-8. 
73. Lachapelle KR, Rathee R, Kratky V, Dexter DF. Treatment of conjunctival mucosa-associated lymphoid tissue lymphoma with intralesional injection of interferon alfa-2b. Arch Ophthalmol. 2000;118(2):284-5.

74. Lucas RS, Mortimore R, Sullivan TJ, Waldie M. Interferon treatment of childhood conjunctival lymphoma. Br J Ophthalmol. 2003;87(9):1191.

75. Ross JJ, Tu KL, Damato BE. Systemic remission of non-Hodgkin's lymphoma after intralesional interferon alpha-2b to bilateral conjunctival lymphomas. Am J Ophthalmol. 2004;138(4):672-3.

76. Zayed M, Sears K, Salvi SM, Rundle PA, Rennie IG, Mudhar HS. Intra-lesional interferon injection for recurrent conjunctival MALT lymphoma. Eye (Lond). 2013;27(5):680-2.

77. Zinzani PL, Magagnoli M, Ascani S, Ricci P, Poletti V, Gherlinzoni F, et al. Nongastrointestinal mucosa-associated lymphoid tissue (MALT) lymphomas: clinical and therapeutic features of 24 localized patients. Ann Oncol. 1997:8:883-6.

78. Zinzani PL, Magagnoli M, Galieni P, Martelli M, Poletti V, Zaja F, et al. Nongastrointestinal low-grade mucosa-associated lymphoid tissue lymphoma: analysis of 75 patients. J Clin Oncol. 1999;17(4):1254-8.

79. Crespo Robledo P, Vázquez Castillo MJ. Intralesional rituximab in ocular adnexal lymphoma. Farm Hosp. 2014;38(4):386-7.

80. Ferreri A, Govi S, Colucci A, Crocchiolo R, Modorati G. Intralesional rituximab: a new therapeutic approach for patients with conjunctival lymphomas. Ophthalmology. 2011;118(1):24-8.

81. Rodríguez Villa S, Ruiz Rodríguez M, Vargas Pabón M. Intralesional rituximab in primary conjunctival follicular lymphoma relapsed. Arch Soc Esp Oftalmol. 2017;92:326-9

82. Abramson DH, Rollins I, Coleman M. Periocular mucosa-associated lymphoid/low grade lymphomas: treatment with antibiotics. Am J Ophthalmol. 2005;140(4):729-30.

83. Danilko L, Haas K, Schönherr U, Tschurtschenthaler G. Clarithromycin therapy of B cell MALT lymphoma. Ophthalmologe. 2013;110(5):447-50.

84. Ferreri AJ, Ponzoni M, Guidoboni M, Resti AG, Politi LS, Cortelazzo S, et al. Bacteria-eradicating therapy with doxycycline in ocular adnexal MALT lymphoma: a multicenter prospective trial. J Natl Cancer Inst. 2006; 98(19):1375-82

85. Govi S, Dognini GP, Licata G, Crocchiolo R, Resti AG, Ponzoni M, et al. Sixmonth oral clarithromycin regimen is safe and active in extranodal marginal zone B-cell lymphomas: final results of a single-centre phase II trial. $\mathrm{Br}$ J Haematol. 2010;150(2):226-9.

86. Grünberger B, Hauff W, Lukas J, Wöhrer S, Zielinski CC, Streubel B, et al. 'Blind' antibiotic treatment targeting Chlamydia is not effective in patients with MALT lymphoma of the ocular adnexa. Ann Oncol. 2006;17(3):484-7.

87. Höh H, Armbrust S, Decker T, Holland U, Balschat S. MALT Iymphoma of the conjunctiva in a 13-year old child--5-year relapse-free follow-up following antibiotic treatment. Klin Monatsbl Augenheilkd. 2016;233(1):79-84.

88. Ésik O, Ikeda H, Mukai K, Kaneko A. A retrospective analysis of different modalities for treatment of primary orbital non-Hodgkin's lymphomas. Radiother Oncol. 1996;38(1):13-8.

89. Tsai PS, Colby KA. Treatment of conjunctival lymphomas. Semin Ophthalmol. 2005;20(4):239-46.

90. Tanimoto K, Kaneko A, Suzuki S, Sekiguchi N, Watanabe T, Kobayashi Y, et al. Primary ocular adnexal MALT lymphoma: a long-term follow-up study of 114 patients. Jpn J Clin Oncol. 2007;37(5):337-44.

91. Yoon JS, Ma KT, Kim SJ, Kook K, Lee SY. Prognosis for patients in a Korean population with ocular adnexal lymphoproliferative lesions. Ophthalmic Plast Reconstr Surg. 2007;23(2):94-9.

92. Mikkelsen LH, Würtz NS, Heegaard S. Recent advances in treating extraocular lymphomas. Expert Rev Ophthalmol. 2018;13(4):205-17.

93. Goda JS, Le LW, Lapperriere NJ, Millar BA, Payne D, Gospodarowicz MK, et al. Localized orbital mucosa-associated lymphoma tissue lymphoma managed with primary radiation therapy: efficacy and toxicity. Int J Radiat Oncol Biol Phys. 2011;81(4):e659-66.

94. Harada K, Murakami N, Kitaguchi M, Sekii S, Takahashi K, Yoshio K, et al. Localized ocular adnexal mucosa-associated lymphoid tissue lymphoma treated with radiation therapy: a long-term outcome in 86 patients with 104 treated eyes. Int J Radiat Oncol Biol Phys. 2014; 88(3):650-4

95. Chao CK, Lin HS, Devineni VR, Smith M. Radiation therapy for primary orbital lymphoma. Int J Radiat Oncol Biol Phys. 1995;31(4):929-34.

96. Reddy EK, Bhatia P, Evans RG. Primary orbital lymphomas. Int J Radiat Oncol Biol Phys. 1988;15(5):1239-41.
97. Platanias LC, Putterman AM, Vijayakumar S, Recant W, Weichselbaum RR, Bitran JD. Treatment and prognosis of orbital non-Hodgkin's lymphomas. Am J Clin Oncol. 1992;15(1):79-83.

98. Yahalom J, Illidge T, Specht L, Hoppe RT, Li YX, Tsang R, et al. Modern radiation therapy for extranodal lymphomas: field and dose guidelines from the international lymphoma radiation oncology group. Int J Radiat Oncol Biol Phys. 2015;92(1):11-31.

99. Sasai K, Yamabe H, Dodo Y, Kashii S, Nagata Y, Hiraoka M. Non-Hodgkin's lymphoma of the ocular adnexa. Acta Oncol. 2001;40(4):485-90.

100. Tsang RW, Gospodarowicz MK, Pintilie M, Wells W, Hodgson DC, Sun A Localized mucosa-associated lymphoid tissue lymphoma treated with radiation therapy has excellent clinical outcome. J Clin Oncol. 2003; 21(22):4157-64.

101. Pinnix CC, Dabaja BS, Milgrom SA, Smith GL, Abou Z, Nastoupil L, et al. Ultra-low-dose radiotherapy for definitive management of ocular adnexal Bcell lymphoma. Head Neck. 2017;39(6):1095-100.

102. Shome D, Esmaeli B. Targeted monoclonal antibody therapy and radioimmunotherapy for lymphoproliferative disorders of the ocular adnexa. Curr Opin Ophthalmol. 2008;19(5):414-21.

103. Bessell EM, Henk JM, Whitelocke RA, Wright JE. Ocular morbidity after radiotherapy of orbital and conjunctival lymphoma. Eye (Lond). 1987;1(Pt 1):90-6.

104. Blasi MA, Gherlinzoni F, Calvisi G, Sasso P, Tani M, Cellini M, et al. Local chemotherapy with interferon-a for conjunctival mucosa-associated lymphoid tissue lymphoma: a preliminary report. Ophthalmology. 2001; 108(3):559-62.

105. Cvetković RS, Perry CM. Rituximab: a review of its use in non-Hodgkin's lymphoma and chronic lymphocytic leukaemia. Drugs. 2006;66:791-820.

106. Sullivan TJ, Grimes D, Bunce I. Monoclonal antibody treatment of orbital lymphoma. Ophthal Plast Reconstr Surg. 2004;20(2):103-6.

107. Good LM, Miller MD, High WA. Intralesional agents in the management of cutaneous malignancy: a review. J Am Acad Dermatol. 2011;64(2):413-22.

108. Laurenti L, De Padua L, Battendieri R, Tarnani M, Sica S, Blasi MA, et al. Intralesional administration of rituximab for treatment of CD20 positive orbital lymphoma: safety and efficacy evaluation. Leuk Res. 2011;35(5):682-4.

109. Savino G, Battendieri R, Gari M, Grazia Caputo C, Laurenti L, Blasi MA. Longterm outcomes of primary ocular adnexal lymphoma treatment with intraorbital rituximab injections. J Cancer Res Clin Oncol. 2013;139(7):1251-5.

110. Demirci H, Kauh CY, Rajaii F, Elner VM. Intralesional rituximab for the treatment of recurrent ocular adnexal lymphoma. Ophthalmic Plast Reconstr Surg. 2017;33(3S Suppl 1):S70-1.

111. Rodríguez Villa S, Ruiz Rodríguez MJ, Vargas Pabón M. Intralesional rituximab in primary conjunctival follicular lymphoma relapsed. Arch Soc Esp Oftalmol. 2017;92(7):326-9.

112. Ferreri AJ, Ponzoni M, Guidoboni M, De Conciliis C, Resti AG, Mazzi B, et al. Regression of ocular adnexal lymphoma after Chlamydia psittaci-eradicating antibiotic therapy. J Clin Oncol. 2005;23(22):5067-73.

113. Kim TM, Kim KH, Lee MJ, Jeon YK, Lee SH, Kim DW, et al. First-line therapy with doxycycline in ocular adnexal mucosa-associated lymphoid tissue lymphoma: a retrospective analysis of clinical predictors. Cancer Sci. 2010; 101(5):1199-203.

114. Han JJ, Kim TM, Jeon YK, Kim MK, Khwarg SI, Kim CW, et al. Long-term outcomes of first-line treatment with doxycycline in patients with previously untreated ocular adnexal marginal zone B cell lymphoma. Ann Hematol. 2015;94:575-81.

115. Kiesewetter B, Lukas J, Kuchar A, Mayerhoefer ME, Müllauer L, Raderer M Clarithromycin leading to complete remission in the first-line treatment of ocular adnexal mucosa-associated lymphoid tissue lymphoma. J Clin Oncol. 2015;33(35):e130-2.

116. Bellisi G, di Lollo S, Bosi A, Bernardi F, Campana G, Romagnani S, et al. Primary conjunctival lymphoma: response to chemotherapy in 4 cases. Acta Haematol. 1982;68(2):161-2.

117. Annibali O, Chiodi F, Sarlo C, Cortes M, Quaranta-Leoni FM, Quattrocchi C, et al. Rituximab as single agent in primary MALT lymphoma of the ocular adnexa. Biomed Res Int. 2015;2015:895105.

118. Celiker H, Toker E, Kaygusuz Atagunduz I. A case of conjunctival MALT lymphoma: successfully treated with solely extended rituximab therapy. Int Ophthalmol. 2019;39(3):687-91.

119. Ferreri AJ, Ponzoni M, Martinelli G, Muti G, Guidoboni M, Dolcetti R, et al. Rituximab in patients with mucosal-associated lymphoid tissuetype lymphoma of the ocular adnexa. Haematologica. 2005;90(11): 1578-9. 
120. Nückel H, Meller D, Steuhl K, Dührsen U. Anti-CD20 monoclonal antibody therapy in relapsed MALT lymphoma of the conjunctiva. Eur J Haematol. 2004;73(4):258-62

121. Rigacci L, Nassi L, Puccioni M, Mappa S, Polito E, Dal Pozzo S, et al. Rituximab and chlorambucil as first-line treatment for low-grade ocular adnexal lymphomas. Ann Hematol. 2007:86(8):565-8.

122. Salepci T, Seker M, Kurnaz E, Guler DO, Bilici A, Dane F, et al. Conjunctival malt lymphoma successfully treated with single agent rituximab therapy. Leuk Res. 2009;33(3):e10-3.

123. Sallak A, Besson FL, Pomoni A, Christinat A, Adler M, Aegerter JP, et al. Conjunctival MALT lymphoma: utility of FDG PET/CT for diagnosis, staging, and evaluation of treatment response. Clin Nucl Med. 2014; 39(3):295-7.

124. Tuncer S, Tanyıldız B, Basaran M, Buyukbabani N, Dogan O. Systemic rituximab immunotherapy in the management of primary ocular adnexal lymphoma: single institution experience. Curr Eye Res. 2015; 40(8):780-5.

125. Wall PB, Traboulsi El, Hsi ED, Singh AD. Bilateral conjunctival follicular lymphoma in a child. J AAPOS. 2015;19(2):183-5.

126. Zinzani PL, Alinari L, Stefoni V, Loffredo A, Pichierri P, Polito E. Rituximab in primary conjunctiva lymphoma. Leuk Res. 2005;29:107-8.

127. Esmaeli B, McLaughlin P, Pro B, Samaniego F, Gayed I, Hagemeister F, et al. Prospective trial of targeted radioimmunotherapy with Y-90 ibritumomab tiuxetan (Zevalin) for front-line treatment of early-stage extranodal indolent ocular adnexal lymphoma. Ann Oncol. 2009;20:709-14.

128. Oellers P, Savar A, Samaniego F, Pro B, Esmaeli B. Second-line 90Yttriumibritumomab tiuxetan (Zevalin) in a patient with conjunctival mucosaassociated lymphoid tissue lymphoma refractory to rituximab. Ophthalmic Plast Reconstr Surg. 2012;28(6):e145-6.

129. Bessell EM, Henk JM, Wright JE, Whitelocke RA. Orbital and conjunctival lymphoma treatment and prognosis. Radiother Oncol. 1988;13:237-44.

130. Woolf DK, Ahmed M, Plowman PN. Primary lymphoma of the ocular adnexa (orbital lymphoma) and primary intraocular lymphoma. Clin Oncol (R Coll Radiol). 2012;24(5):339-44.

131. Decaudin D, de Cremoux P, Vincent-Salomon A, Dendale R, Rouic LL. Ocular adnexal lymphoma: a review of clinicopathologic features and treatment options. Blood. 2006;108(5):1451-60.

132. Ning F, Ye J, Wei LQ, Li X, Wang JW. Efficacy of chemotherapy as a first-line treatmentin patients with ocular adnexal MALT lymphoma. Zhongguo Shi Yan Xue Ye Xue Za Zhi. 2012;20(4):912-6.

133. Derenzini $\mathrm{E}$, Zinzani PL, Cheson BD. Bendamustine: role and evidence in lymphoma therapy, an overview. Leuk Lymphoma. 2014;55(7):1471-8.

134. Martin P, Chen Z, Cheson BD, Robinson KS, Williams M, Rajguru SA, et al. Long-term outcomes, secondary malignancies and stem cell collection following bendamustine in patients with previously treated non-Hodgkin lymphoma. Br J Haematol. 2017;178(2):250-6.

135. Gil L, Kazmierczak M, Kroll-Balcerzak R, Komarnicki M. Bendamustine-based therapy as first-line treatment for non-Hodgkin lymphoma. Med Oncol. 2014;31(5):944

136. Rummel MJ, Al-Batran SE, Kim SZ, Welslau M, Hecker R, Kofahl-Krause D, et al. Bendamustine plus rituximab is effective and has a favorable toxicity profile in the treatment of mantle cell and low-grade non-Hodgkin's lymphoma. J Clin Oncol. 2005;23(15):3383-9.

137. Lossos IS, Fabregas JC, Koru-Sengul T, Miao F, Goodman D, Serafini AN, et al. Phase II study of (90)Y Ibritumomab tiuxetan (Zevalin) in patients with previously untreated marginal zone lymphoma. Leuk Lymphoma. 2015;56(6):1750-5

138. Ben Simon GJ, Cheung N, McKelvie P, Fox R, McNab AA. Oral chlorambucil for extranodal, marginal zone, B-cell lymphoma of mucosa-associated lymphoid tissue of the orbit. Ophthalmology. 2006;113(7):1209-13.

139. Song E, Kim S, Kim T, Lee KW, Yun T, Na Il, et al. Efficacy of chemotherapy as a first-line treatment in ocular adnexal extranodal marginal zone B-cell lymphoma. Ann Oncol. 2008;19(2):242-6.

140. Luque Valentin-Fernandez ML, Alvarez Rodríguez F, Rodríguez Jiménez I. Favourable response to rituximab by an ocular adnexal primary lymphoma. Arch Soc Esp Oftalmol. 2016;91(11):539-42.

141. Zucca E, Conconi A, Martinelli G, Bouabdallah R, Tucci A, Vitolo U, et al. Final results of the IELSG-19 randomized trial of mucosa-associated lymphoid tissue lymphoma: improved event-free and progression-free survival with rituximab plus chlorambucil versus either chlorambucil or rituximab monotherapy. J Clin Oncol. 2017;35(17):1905-12.
142. Esmaeli B, Murray JL, Ahmadi MA, Naderi A, Singh S, Romaguera J, et al. Immunotherapy for low-grade non-hodgkin secondary lymphoma of the orbit. Arch Ophthalmol. 2002;120(9):1225-7.

143. Nakata M, Matsuno $Y$, Katsumata N, Takenaka T, Kobayashi Y, Narabayashi M, et al. Histology according to the Revised European-American Lymphoma Classification significantly predicts the prognosis of ocular adnexal lymphoma. Leuk Lymphoma. 1999;32(5-6):533-43.

144. Kirkegaard MM, Rasmussen PK, Coupland SE, Esmaeli B, Finger PT, Graue GF, et al. Conjunctival lymphoma-an international multicenter retrospective study. JAMA Ophthalmol. 2016;134(4):406-14.

145. Sjö LD, Heegaard S, Prause JU, Petersen BL, Pedersen S, Ralfkiaer E. Extranodal marginal zone lymphoma in the ocular region: clinical, immunophenotypical, and cytogenetical characteristics. Invest Ophthalmol Vis Sci. 2009;50(2):516-22.

146. Coupland SE, Hellmich M, Auw-Haedrich C, Lee WR, Stein H. Prognostic value of cell-cycle markers in ocular adnexal lymphoma: an assessment of 230 cases. Graefes Arch Clin Exp Ophthlmol. 2004;242(2):130-45.

147. Meunier J, Lumbroso-Le Rouïc L, Vincent-Salomon A, Dendale R, Asselain B, Arnaud $P$, et al. Ophthalmologic and intraocular non-Hodgkin's lymphoma: a large single Centre study of initial characteristics, natural history, and prognostic factors. Hematol Oncol. 2004;22:143-58.

148. Bayraktar S, Bayraktar UD, Stefanovic A, Lossos IS. Primary ocular adnexal mucosa-associated lymphoid tissue lymphoma (MALT): single institution experience in a large cohort of patients. Br J Haematol. 2011;152(1):72-80.

149. Jenkins C, Rose GE, Bunce C, Cree I, Norton A, Plowman PN, et al. Clinical features associated with survival of patients with lymphoma of the ocular adnexa. Eye (Lond). 2003;17:809-20.

150. Thieblemont C, Berger F, Dumontet C, Moullet I, Bouafia F, Felman P, et al. Mucosa-associated lymphoid tissue lymphoma is a disseminated disease in one third of 158 patients analyzed. Blood. 2000;95(3):802-6.

\section{Ready to submit your research? Choose BMC and benefit from:}

- fast, convenient online submission

- thorough peer review by experienced researchers in your field

- rapid publication on acceptance

- support for research data, including large and complex data types

- gold Open Access which fosters wider collaboration and increased citations

- maximum visibility for your research: over $100 \mathrm{M}$ website views per year

At BMC, research is always in progress.

Learn more biomedcentral.com/submissions 